UDC 615.322:582.661.41

Original research paper

doi: 10.5937/AASer1846223M

Acta Agriculturae Serbica, Vol. XXIII, 46 (2018); 223-231

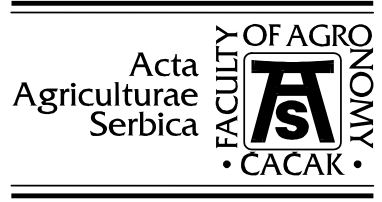

\title{
Determination of the content of bioactive components in different extracts of Portulaca oleracea L.
}

\author{
Jelena Mladenović ${ }^{1}$, Milena Đurić ${ }^{1}$, Gordana Šekularac ${ }^{1}$, Duško \\ Brković $^{1}$, Jelena Stepanović ${ }^{1}$, Pavle Mašković ${ }^{1}$, Ljiljana Bošković- \\ Rakočević ${ }^{1}$ \\ ${ }^{1}$ University of Kragujevac, Faculty of Agronomy, Cara Dusana 34, 32000 \\ Čačak,Serbia \\ Corresponding author: jelenamala@kg.ac.rs
}

\begin{abstract}
Plants can be very useful as soil guards, and as an additional source of vitamins and minerals in human nutrition. Some, of them also have medicinal properties. Portulaca oleracea L. contains more antioxidants than spinach. It is also rich in vitamins $\mathrm{C}$ and $\mathrm{B}$, including riboflavin, pyridoxine,niacin, carotenoids and traces of minerals such as iron, magnesium and calcium. The following analyses were carried out: determination of moisture in the plant material, preparation of macerates, extraction of samples in the Soxhlet apparatus, ultrasonic extraction of samples, determination of extract density by an aerometer, determination of extraction yield by maceration, determination of extraction yield by Soxhlet extraction, determination of extraction yield by ultrasonic extraction and determination of the content of vitamin $\mathrm{C}$ in the extracts obtained. The dry matter content obtained on the basis of three measurements was $7.679 \%$ and the moisture content was $92.321 \%$. The smallest extraction yield was obtained by Soxhlet extraction $0.1625 \mathrm{~g}$, followed by maceration $0.3575 \mathrm{~g}$ and ultrasonic extraction $0.775 \mathrm{~g}$. The highest density was determined for the ultrasonic extract $0.85 \mathrm{~g} / \mathrm{cm}^{3}$, and the smallest for the Soxhlet's extract $0.70 \mathrm{~g} / \mathrm{cm}^{3}$, which was correlated with extraction yields. The content of vitamin C was highest in the ultrasonic extract $15.5 \mathrm{mg} / 100 \mathrm{~g}$, slightly lower in the macerate extract $6.5 \mathrm{mg} / 100 \mathrm{~g}$, and the smallest in the Soxhlet's extract $2.5 \mathrm{mg} / 100 \mathrm{~g}$. The content of bioactive components in purslane leaf depends on the extraction method.
\end{abstract}

Received 30 October 2018 Accepted 28 November 2018 
Ultrasonic extraction proved to be the most optimal method, giving the highest extraction yield and the highest vitamin $C$ content. It lasted for a minimum period of time (30 min) and extraction temperature was the lowest $40{ }^{\circ} \mathrm{C}$. We assume that under these conditions vitamin $\mathrm{C}$ is rapidly extracted and preserved from degradation.

Keywords: bioactive components, Portulaca oleracea L., vitamin C.

\section{Introduction}

Research is increasingly focused on testing the use of plant extracts and essential oils, isolated from medicinal herbs, in the food industry, to extend the shelf life of foodstuffs and improve their quality. The characteristic properties of plants have been known since the earliest times of human civilization. To this day, plants have been used as food, medicines, preservatives, for religious purposes, as decoration, etc. Until the emergence of chemistry, and especially until the synthesis of organic molecules in the 19th century, plants were the exclusive source of pharmacologically active substances (Mac Vicar, 2006).

Strange as it may sound, weed plants are very useful as soil protectors, and as an additional source of vitamins and minerals in human nutrition. Many of them also have medicinal properties. Because of the structure of their roots, weed plants bring minerals from deeper layers of soil, by crushing and degrading residual solid parts of plants. As a rule, weed plants are richer in vitamins and minerals than cultivated plants. "reen index fingers", testify to our bad treatment of soil and they grow abundantly in places where man has neglected the land or disturbed the soil's natural balance (Šilješ et al., 1992).

Researchers have found that purslane contains more antioxidants than spinach and that the concentration of omega-3 fatty acids is higher than the amount found in some fish oils. Starting from the above facts, the aim of the present research was to examine the extracts of Portulaca oleracea L. obtained by various methods of extraction and determine their vitamin C content. Given the potential use of this plant in the pharmaceutical and food industries, the most optimal conditions for extraction of this plant, which is known for its high content of vitamin C (Savković, 2001), were examined.

In terms of chemical structure and biochemical functions, vitamins are a heterogeneous group of organic compounds of diverse structures and chemical properties, necessary for proper growth, development and functioning of an organism. Plants synthesize virtually all vitamins. The biological importance of vitamins is that they are mostly coenzymes of various enzymes. The vitamin content of foods is influenced by a number of factors: the presence of oxygen, light, the presence of metal ions (Kujundžić, 2002). Portulaca oleracea L. is rich in vitamin $\mathrm{A}$. It is also rich in vitamins $\mathrm{C}$ and $\mathrm{B}$, including riboflavin, pyridoxine, niacin, carotenoids and traces of minerals such as iron, magnesium and calcium (Lampe, 1999). 
Ascorbate (ions of ascorbic acid) is necessary in a series of essential metabolic reactions in all plants and animals. In living organisms, ascorbate acts as an antioxidant to protect the body against oxidative stress (Kelly et al., 1996). Vitamin C is one of the most widely used food additives. It regulates cholesterol catabolism in bile acids and has been demonstrated to be an important factor in the regulation of fat in various animal models (Kaur et al., 2001). Ascorbic acid is present in chloroplasts and has numerous roles in cell division and protein modification. The daily requirement for this vitamin is $50-60 \mathrm{mg}$ for healthy people, and about $2 \mathrm{~g}$ per day for people who smoke, as they are exposed to pollution, stress, illnesses. It improves the circulation of iron in the body and increases resistance of the organism.

Vitamin C deficiency causes generalized weakness, anemia and is associated with osteoporosis. Chronic lack of vitamin $\mathrm{C}$ in the body leads to scurvy. The most common cause is inadequate nutrition. Vitamin $\mathrm{C}$ is the most sensitive of all hydrosoluble vitamins. Its lowest contents are found in the underground parts of plants. Vitamin C is the only substance that exhibits reducing power in acidic solutions. It has a very strong effect in reducing cholesterol concentrations by $10-20 \%$. It is able to completely stop malignant cell transformation (Lee and Kader, 2000). There is evidence that people who ingest sufficient amounts of vitamin $\mathrm{C}$ through healthy nutrition and dietary supplements have a lower chance of suffering from heart diseases, stroke, peripheral arterial disease, hypertension, asthma and some types of cancer (Prat and Birac, 1979).

Portulaca oleracea L. (Figure 1) belongs to the family of Portulacaceae. The plant is of North American or Central Asian origin, and is spread throughout Europe. In Serbia, purslane grows mainly as a self-contained plant along houses and roads, in sunny places. It occurs only up to $800 \mathrm{~m}$ above sea level. It is easy to recognize, branching over the ground, and has a round red-colored stem, with round green leaves of waxy appearance (Sarić, 1989).

Figure 1. Portulaca oleracea L.

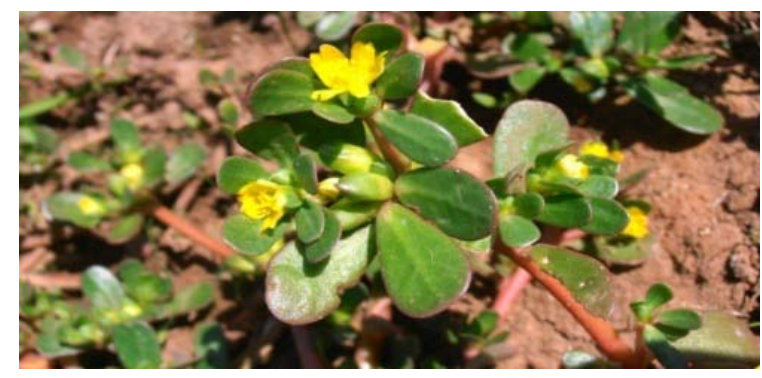


Portulaca oleracea L. is 15-30 cm in height. The tree is fleshy, bare, curvy, subtle and branched. The leaves are oval, alternate, fleshy, shiny, reddish on the edges. The plant flourishes from July to September. The flowers are small, yellow. They grow individually or in groups of 2-3. The fruit is a shell. The seed is kidney-shaped, flaky. The plant is used as a spicy flavour, for various dishes or waffles (Stilinović, 1987). It, also has antibacterial and antifungal effects. When used fresh, Portulaca oleracea L. is a diuretic and a mild laxative; therefore, it is the perfect plant for weight loss. The plant contains an impressive amount of alpha-linolenic acid, an essential omega-3 fatty acid, which places it at the very top of plants with high concentrations of this substance. It is a powerful antioxidant that can protect the liver from one of the most harmful things paracetamol (Lajišić and Grujić, 1998). It contains two types of betalain alkaloid pigments: red, which is visible in the color of the stem, and yellow, expressed in flowers and in yellowish leaves. It is called "icy grass" because it is an ideal summer plant, it cools the body and alleviates headaches caused by exposure to strong sunshine (Šilješ et al., 1992).

\section{Material and methods}

In the experimental part of this work, the following analyses were performed: determination of moisture in the plant material, preparation of macerates, sample extraction in the Soxlet apparatus, ultrasonic extraction of samples, determination of extract density by an aerometer, determination of extraction yield by maceration, determination of extraction yield by Soxhlet extraction, Determination of extraction yield by ultrasonic extraction, determination of the vitamin $\mathrm{C}$ content in the extracts obtained.

The material used was purslane (Portulaca oleracea L.). The plant material was collected in November 2017, at the Čačak locality. After sampling, the plant material (leaves) was purified, crushed and prepared for further analysis. Extracts were obtained from fresh plants.

Soxhlet extraction was carried out using conventional apparatus, while ultrasound extraction was performed in an ultrasonic water bath (EUP540A, Euinstruments, France). The sample (5 g) was placed in a round-bottom flask and $250 \mathrm{ml}$ of $96 \%$ ethanol was added. The mixture was extracted for 30 minutes at a frequency of $40 \mathrm{kHz}$ and ultrasound power of $90 \%$ (216 W). Density was determined using an aerometer.

The quantitative determination of total vitamin $\mathrm{C}$ was based on the reversible ability of the oxi doreduction system as given by the relations between ascorbic acid and dehydroascorbic acid. For the quantitative determination of vitamin $\mathrm{C}$, the Tillmans (Tillmans) method was used, based on titration, in which Lascorbic acid was oxidized to dehydroascorbic acid, while simultaneously 
reducing the reagent used. Titration was performed using 2,6dichlorophenolinophenol, i.e. Tillmans's Reagent (TR).

The mixture was transferred to 3 flasks with $2 \mathrm{ml}$ solution of ascorbic acid $\left(\mathrm{C}_{6} \mathrm{H}_{8} \mathrm{O}_{6}, \mathrm{c}=1 \mathrm{mg} / \mathrm{ml}\right)$ and $5 \mathrm{ml}$ solution of $\mathrm{HPO}_{3}$ mixture and glacial $\mathrm{CH}_{3} \mathrm{COOH}$. The probes immediately titrated the TR to a pinkish color, lasting for about 5 seconds. To calculate the titre, the mean value of the volume of the TR solution used for titration was taken. The titre was expressed as mg C6H8O6 per $1 \mathrm{~mL}$ TR. Along with the TR solution, blank titration was performed under the same intensity of the pink color.

\section{Results and discussion}

The results of Content and percentage of dry matter in Portulaca oleracea L. Leaves, Percentage extraction yield, Determination of extract density and Determination of vitamin C content were presented in Table (1-4).

Table 1. Content and percentage of dry matter in Portulaca oleracea L. leaves

\begin{tabular}{|c|c|c|}
\hline Weight before drying & Weight after drying & dry matter, \% \\
\hline 5.014 & 0.402 & 8.017 \\
\hline 5.035 & 0.350 & 6.951 \\
\hline 5.019 & 0.405 & 8.069 \\
\hline
\end{tabular}

The analysis was done in three tests and the mean was calculated.

\begin{tabular}{|c|c|c|}
\hline 5.014 g -------- 100 \% & $\begin{array}{c}5.035 \mathrm{~g} \text {-------- } 100 \% \\
100 \%\end{array}$ & 5.019 g -------- \\
\hline $\begin{array}{l}0.402 \text { g---------X \% } \\
\%\end{array}$ & 0.350 g---------X \% & 0.405 g---------x \\
\hline
\end{tabular}

$\mathrm{X} 1=8.017 \%$ dry matter, $\mathrm{X} 2=6.951 \%$ dry matter, $\mathrm{X} 3=8.069 \%$ dry matter

$$
\begin{gathered}
\% \mathrm{H} 2 \mathrm{O}=100-8.017=91.983 ; \\
\% \mathrm{H} 2 \mathrm{O}=100-6.951=93.049 ; \\
\% \mathrm{H} 2 \mathrm{O}=100-8.069=91.931 ; \\
\overline{\mathrm{X}}=(\mathrm{X} 1+\mathrm{X} 2+\mathrm{X} 3) / 3=7.679 \% \text { dry matter } \\
\% \mathrm{H} 2 \mathrm{O}=(91.983+93.049+91.931) / 3=92.321
\end{gathered}
$$


The dry matter content obtained on the basis of three measurements was calculated as their mean value, and amounted to $7.679 \%$. The moisture content obtained by subtracting the dry matter content per $100 \mathrm{~g}$ of the sample for each measurement was also expressed as their mean value, and was $92.321 \%$.

\section{Total extraction yield}

After extraction, evaporation of extracts to dryness and measurement of dry residues, extraction yield was calculated. From $5 \mathrm{~g}$ of the herbal material of Portulaca oleracea L., 0.3575 g of macerate dry matter, 0.1625 g of Soxhlet extract and $0.775 \mathrm{~g}$ of ultrasonic extract were obtained. The results were presented as percentages in Table 2.

Table 2. Percentage extraction yield

\begin{tabular}{|c|c|c|c|}
\hline Sample & Maceration & Soxhlet extraction & $\begin{array}{c}\text { Ultrasonic } \\
\text { extraction }\end{array}$ \\
\hline Leaf & $7.15 \%$ & $3.25 \%$ & $15.5 \%$ \\
\hline
\end{tabular}

The results showed that the smallest yield was obtained by Soxhlet extraction, followed by maceration, while the highest yield was obtained by ultrasonic extraction, which proved optimal for the plant. Given that the plant contains a lot of vitamins and bioactive compounds, it is assumed that Soxhlet's extraction resulted in the degradation of these thermolabile compounds, and maceration was influenced by extraction length.

Table 3. Determination of extract density

\begin{tabular}{|c|c|}
\hline Type of extraction & $\mathbf{g} / \mathbf{c m}^{\mathbf{3}}$ \\
\hline Maceration & 0.78 \\
\hline Soxhlet extraction & 0.70 \\
\hline Ultrasonic extraction & 0.85 \\
\hline
\end{tabular}

Based on density measurements, maximum density was obtained for the ultrasonic extract $0.85 \mathrm{~g} / \mathrm{cm}^{3}$, and the smallest for the Soxhlet's extract $0.70 \mathrm{~g} /$ $\mathrm{cm}^{3}$, which was correlated with extraction yields. 
Table 4. Determination of vitamin C content

\begin{tabular}{|c|c|}
\hline Type of extraction & Vitamin C mg / 100 g extracts \\
\hline Maceration & 6.5 \\
\hline Soxhlet extraction & 2.5 \\
\hline Ultrasonic extraction & 15.5 \\
\hline
\end{tabular}

The highest vitamin $\mathrm{C}$ content was determined, in the extracts obtained by ultrasonic extraction $15.5 \mathrm{mg} / 100 \mathrm{~g}$, followed by maceration $6.5 \mathrm{mg} / 100 \mathrm{~g}$, and Soxhlet extraction $2.5 \mathrm{mg} / 100 \mathrm{~g}$. Ultrasonic extraction resulted in the isolation of the largest amount of this vitamin because temperature was $40{ }^{\circ} \mathrm{C}$, lower than the degradation temperature for this vitamin $\left(50-60{ }^{\circ} \mathrm{C}\right)$. During Soxhlet extraction, solvent temperature was at the boiling point i.e. $60{ }^{\circ} \mathrm{C}$, and during maceration, if the solvent was at room temperature, the process lasted for 5 days, which probably led to vitamin degradation. The ultrasonic extraction method proved to be the most optimal, giving the highest yield, since it lasted the shortest period of time (30 $\mathrm{min})$ at the lowest temperature. This is why vitamin $\mathrm{C}$ was rapidly extracted and preserved from degradation.

Three different methods of extraction of purslane (Portulaca oleracea L.) were used. Extraction yields for each extract and vitamin $\mathrm{C}$ contents were determined. The results showed the following: The dry matter content obtained on the basis of three measurements was $7.679 \%$, and the moisture content was 92.321\%. The lowest yield was obtained by Soxhlet extraction $0.1625 \mathrm{~g}$, followed by maceration $0.3575 \mathrm{~g}$ and ultrasonic extraction $0.775 \mathrm{~g}$.The highest density was determined for the ultrasonic extract $0.85 \mathrm{~g} / \mathrm{cm}^{3}$, and the smallest for the Soxhlet's extract $0.70 \mathrm{~g} / \mathrm{cm}^{3}$, which was correlated with extraction yields. The highest vitamin $\mathrm{C}$ content measured in the ultrasonic extract $15.5 \mathrm{mg}$ / $100 \mathrm{~g}$, slightly lower in macerate $6.5 \mathrm{mg} / 100 \mathrm{~g}$, and the smallest in the Soxhlet's extract $2.5 \mathrm{mg} / 100 \mathrm{~g}$.

\section{Conclusion}

The content of bioactive components depends on the extraction method.

The ultrasonic extraction method proved to be the most optimal, giving the highest extraction yield and the highest vitamin content. It lasted for a minimum period of time (30 min) and extraction temperature was the lowest $40{ }^{\circ} \mathrm{C}$. We assume that under these conditions vitamin $\mathrm{C}$ was is rapidly extracted and preserved from degradation. 


\section{Acknowledgements}

This study is part of the TR 31059 project financially supported by the Ministry of Education and Science of the Republic of Serbia.

\section{References}

Kaur C., Kapoor C. (2001): Antioxidant in fruits and vegetables - the millennium'shealth. Journal of Food Science and Technology, 36: 703-735.

Keli S.O., Hertog M.G., Feskens E.J., Kromhont D. (1996): Dietary flavonoids, antioxidant vitamins and incidence of stroke: the Zutphen study. Archives of internal medicine, 156: 637-642.

Kujundžić S. (2002): Biohemijska ispitivanja biljnih vrsta familije Apiaceae: magistarska teza, Novi Sad, Prirodno-matematički fakultet, Institut za hemiju.

Lajšić S., Grujić-Injac B. (1998): Hemija prirodnih proizvoda, Tehnološki fakultet, Novi Sad.

Lampe J.W. (1999): Health effects of vegetables and fruit: assessing mechanisms of action in human experimental studies. The American Journal of Clinical Nutrition, 70: 475-490.

Lee S., Kader A. (2000): Preharvest and postharvest factors influencing vitamin C content of horticultural crops. Postharvest Biology and Technology, 20: 207-220.

Mac Vicar J. (2006): Ljekovito i začinsko bilje, Naklada Uliks, Rijeka.

Prat D.E., Birac P. M. (1979): Source of antioxidant activity of soybeans and so products, Journal of Food Science, 44: 1720-1722.

Sarić M. (1989): Lekovite biljke SR Srbije: 278-279. Beograd, Srbija, SANU.

Savković D. (2001): Enciklpedija lekovitih biljaka, 24: 220-226

Stilinović, S. (1987): Proizvodnja sadnog materijala šumarskog i ukrasnog drveća i žbunja, Univerzitet u Beogradu, Beograd

Šilješ I., Grozdanić G., Grgesina I. (1992): Poznavanje, uzgoj i prerada ljekovitog bilja. Školska knjiga, Zagreb. 


\title{
ODREĐIVANJE SADRŽAJA BIOAKTIVNIH KOMPONENTI U RAZLIČITIM EKSTRAKTIMA PORTULACA OLERACEA L.
}

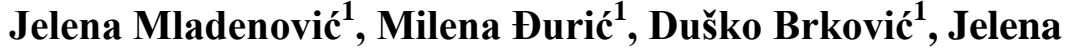 \\ Stepanović $^{1}$, Pavle Mašković ${ }^{1}$ Ljiljana Bošković-Rakočević ${ }^{1}$ \\ ${ }^{1}$ Univerzitet u Kragujevcu, Agronomski fakultet u Čačku, Cara Dušana \\ 34, $32000 \check{C} a c ̌ a k$, Srbija
}

\begin{abstract}
Rezime
Korovske biljke mogu biti veoma korisne kao čuvari zemljišta, a u ljudskoj ishrani kao dodatni izvor vitamina i minerala, neke od njih imaju i lekovita svojstva. Portulaca oleracea L. (tušt) sadrži više antioksidanasa od spanaća, dok je koncentracija omega-3-masnih kiselina veća od količine koja se može naći u nekim ribljim uljima. Takođe, je bogat vitaminom $\mathrm{C}$ i B, uključujući i riboflavin, piridoksin, niacin, karotenoide i tragove minerala poput gvožđa, magnezijuma i kalcijuma. Izvršene su sledeće analize: određivanje vlage u biljnom materijalu, priprema macerata, ekstrakcija uzoraka u Soksletovom aparatu, ultrazvučna ekstrakcija uzoraka, određivanje gustine dobijenih ekstrakata aerometrom, određivanje sadržaja ekstrahovane materije dobijene maceracijom, određivanje sadržaja ekstrahovane materije dobijene Soksletovom ekstrakcijom, određivanje sadržaja ekstrahovane materije dobijene ultrazvučnom ekstrakcijom i određivanje sadržaja vitamina C u dobijenim ekstraktima. Sadržaj suve materije dobijen na osnovu tri merenja je $7.679 \%$, a sadržaj vlage je $92.321 \%$. Najmanji prinos dobijen Soksletovom ekstrakcijom je 0.1625 g, maceracijom $0.3575 \mathrm{~g}$ i $0.775 \mathrm{~g}$ ultrazvučnom ekstrakcijom. Najveća gustina određena je kod ultrazvučnog ekstrakta $0.85 \mathrm{~g} / \mathrm{cm}^{3}$, a najmanja kod Soksletovog ekstrakta $0.70 \mathrm{~g} / \mathrm{cm}^{3}$, što je u korelaciji sa prinosima ekstrakcije. Pri određivanju sadržaja vitamina $\mathrm{C}$, uočili smo da je najveći sadržaj ovog vitamina, takođe kod ultrazvučnog ekstrakta 15.5 $\mathrm{mg} / 100 \mathrm{~g}$, nešto niži kod macerata $6.5 \mathrm{mg} / 100 \mathrm{~g}$, a najmanji sadržaj kod Soksletovog ekstrakta $2.5 \mathrm{mg} / 100 \mathrm{~g}$. Sadržaj bioaktivnih komponenti u listu tušta zavisi od metoda ekstrakcije. Metoda ultrazvučne ekstrakcije se pokazala kao najoptimalnija sa najvećim prinosom ekstrakta i najvećim sadržajem vitamina. Trajala je najmanji vremenski period (30 min), a temperatura ekstrakcije je bila najniža $40^{\circ} \mathrm{C}$. Pretpostavljamo da je pod ovim uslovima vitamin brzo ekstrahovan i očuvan od razgradnje.
\end{abstract}

Ključne reči: bioaktivne komponente, Portulaca oleracea L.,vitamin C. 